\title{
Cross-infection of gastrointestinal nematodes between winter corralled semi-domesticated reindeer (Rangifer tarandus tarandus) and sheep (Ovis aries)
}

\author{
Saana-Maaria Manninen*, Antti Oksanen, Sauli Laaksonen \\ From Parasite infections of domestic animals in the Nordic countries - emerging threats and challenges. \\ The 22nd Symposium of the Nordic Committee for Veterinary Scientific Cooperation (NKVet) \\ Helsinki, Finland. 7-9 September 2008
}

\section{Summary}

The increasing number of sheep (Ovis aries) in the reindeer (Rangifer tarandus tarandus) herding area in North Finland and supplementary winter feeding of reindeer in corrals shared with sheep causes potential for crossinfection of gastrointestinal nematodes between reindeer and sheep. The aim of this study was to elucidate this potential. The study included 46 animals, of which 12 reindeer and 8 sheep had shared a corral. Twelve reindeer had no known contact with sheep. Both reindeer groups shared free ranging areas with wild moose (Alces alces). Two moose were included in this study, as were 12 sheep which had no contact with other ruminants. After slaughter in September-November abomasa and proximal small intestines were collected and examined for gastrointestinal nematodes. The parasites were collected, counted and identified. Following species were found in reindeer: Ostertagia gruehneri, Ostertagia arctica, Spiculopteragia dagestanica, Nematodirus tarandi, Nematodirella longissimespiculata and Bunostomum trigonocephalum. Sheep were infected with Teladorsagia circumcincta, Teladorsagia trifurcata, Ostertagia gruehneri, Ostertagia arctica, Nematodirus filicollis and Nematodirus spathiger. Spiculopteragia dagestanica and Ostertagia gruehneri were identified in moose. Ostertagia gruehneri, which is considered to be a reindeer parasite, was only found in the sheep that had shared a corral with reindeer. These sheep were not

Finnish Food Safety Authority Evira, Fish and Wildlife Health Research Unit, Oulu, Finland

Full list of author information is available at the end of the article found to be infected with other abomasal nematodes. The reindeer that had shared a corral with sheep were not infected with nematodes usually having sheep as their primary host.

Published: 13 October 2010

doi:10.1186/1751-0147-52-S1-S30

Cite this article as: Manninen et al:: Cross-infection of gastrointestinal nematodes between winter corralled semi-domesticated reindeer (Rangifer tarandus tarandus) and sheep (Ovis aries). Acta Veterinaria Scandinavica 2010 52(Suppl 1):S30.
Submit your next manuscript to BioMed Central and take full advantage of:

- Convenient online submission

- Thorough peer review

- No space constraints or color figure charges

- Immediate publication on acceptance

- Inclusion in PubMed, CAS, Scopus and Google Scholar

- Research which is freely available for redistribution

Submit your manuscript at www.biomedcentral.com/submit
C Biomed Central 